\title{
Influence of fertilizer management and water regime on methane emission from rice fields
}

\author{
Arun Kumar Rath ${ }^{\text {a }}$, B. Swain ${ }^{\text {a }}$, B. Ramakrishnan ${ }^{\text {a, }}$, D. Panda ${ }^{\text {a }}$, T.K. Adhya ${ }^{\text {a }}$, V.R. Rao ${ }^{\text {a }}$, \\ N. Sethunathan ${ }^{b}$ \\ ${ }^{a}$ Central Rice Research Institute, Cuttack 753 006, India \\ ${ }^{\mathrm{b}}$ Indian Agricultural Research Institute, New Delhi 110 012, India
}

Received 10 September 1998; received in revised form 6 May 1999; accepted 31 May 1999

\begin{abstract}
Experiments were conducted to determine methane emission from a rainfed lowland rice field (water depth about 3-30 cm) and an irrigated shallow rice field $(4-6 \mathrm{~cm})$, both planted to the same cultivar, cv. 'Gayatri,' as influenced by fertilizer management practices. Methane emission peaked from 100 to 125 days after transplanting followed by a decline in rainfed lowland field plots. Application of prilled urea did not enhance methane emission significantly over that of the untreated control. Subsurface application of urea supergranules was, however, effective in reducing the methane flux over that of the control. Methane emission was lowest in plots treated with the mixture of prilled urea and Nimin (a nitrification inhibitor). Under irrigated shallow conditions, the application of prilled urea and green manure (Sesbania rostrata), singly and in combination, significantly increased methane emission over that of the control. Cumulative methane efflux from control and prilled urea treated lowland rice field was about 4-10 times higher than that in irrigated shallow fields. These results suggest that by virtue of their readily mineralizable carbon and ninhydrin reactive nitrogen, these substrates can serve as positive indicators of methane emission potential of rice fields. (C1999 Elsevier Science B.V. All rights reserved.
\end{abstract}

Keywords: Methane emission; Oryza sativa; Water regime; Fertilizers; Green manure; Mitigation; India

\section{Introduction}

Flooded rice fields serve as an important source of atmospheric methane, a greenhouse gas implicated in global warming. There is considerable research worldwide on developing farmer-friendly, eco-friendly and

\footnotetext{
* Corresponding author. Present address: Max-Planck-Institut für Terrestrische Mikrobiologie, Karl-von-Frisch-Str., D-35043 Marburg, Germany. Tel.: +49-6421-178-832; fax: +49-6421-178-809 E-mail address: ramakris@mailer.uni-marburg.de (B. Ramakrishnan)
}

cost-effective technologies to mitigate methane emission from rice fields. Water management is often considered a good strategy to mitigate methane emission from rice fields (Mishra et al., 1997). A single mid-season drainage retarded seasonal methane emission from irrigated rice fields by about $50 \%$ (Kimura, 1992). However, in certain situations as in rainfed lowland rice fields of eastern and northeastern India, drainage of water from rice fields is virtually impossible because of high water tables. Under these situations, mitigation strategies need to be specific to the location. Promising options in such situations can 
include selection and breeding of high yielding rice cultivars with low methane emission potential. In this regard, cultivars with low methane emission from rice fields have been identified especially for irrigated shallow conditions (Adhya et al., 1994; Lindau et al., 1995; Satpathy et al., 1998).

Another option is to regulate the status of soil fertility through fertilizer management. Application of sulphate-containing fertilizers reduces emission from flooded rice soils (Adhya et al., 1998). In contrast, incorporation of organic sources, for instance green manure and rice straw in rice soils stimulates methane emission (Denier van der Gon and Neue, 1995). Likewise, urea, a commonly used nitrogenous fertilizer in Asian countries can increase methane emission from rice fields. Studies have shown that urea applied to puddled lowland rice fields is prone to high gaseous losses, particularly by ammonia volatilization (Mikkelsen et al., 1978) and denitrification to the volatile forms, $\mathrm{N}_{2} \mathrm{O}$ and $\mathrm{N}_{2}$. There is evidence that nitrification inhibitors can increase the $\mathrm{N}$-use efficiency in lowland rice (Prasad and Power, 1995). Besides, nitrification inhibitors can repress $\mathrm{N}_{2} \mathrm{O}$ emissions especially from upland soils (Cribbs and Mills, 1979; Bhadrachalam et al., 1992) and methane emission from flooded soils (Bronson and Mosier, 1991). The present investigation deals with the influence of different fertilizers on methane emission from two sites (planted to a common cultivar).

\section{Materials and methods}

\subsection{Field procedures}

The effect of fertilizer management on methane emission from rice fields was examined at two sites in the experimental farm of Central Rice Research Institute, Cuttack $\left(20^{\circ} 25^{\prime} \mathrm{N}, 85^{\circ} 55^{\prime} \mathrm{E}\right)$ during the wet season (June-November) of 1996. One site represented a typical rainfed lowland rice field with water depth up to $30 \mathrm{~cm}$ and the other site represented an irrigated shallow rice field with a water depth of $4-6 \mathrm{~cm}$. Rice has been grown in these plots under the respective water regimes for the past 50 years. The field site preparation and the experimental details were basically the same as reported by Adhya et al.
Table 1

Characteristics of soil samples from the experimental sites

\begin{tabular}{|c|c|c|}
\hline Soil characteristic & $\begin{array}{l}\text { Rainfed } \\
\text { lowland }\end{array}$ & $\begin{array}{l}\text { Irrigated } \\
\text { shallow }\end{array}$ \\
\hline $\mathrm{pH}(1: 2$ soil : water ratio) & 6.40 & 7.63 \\
\hline $\begin{array}{l}\text { Electrical conductivity }\left(\mathrm{dS} \mathrm{m}^{-1} \text {, }\right. \\
1: 2 \text { soil:water ratio) }\end{array}$ & 0.78 & 2.03 \\
\hline Water holding capacity (\%) & 50.0 & 47.1 \\
\hline Organic carbon $(\%)$ & 0.57 & 0.51 \\
\hline Total nitrogen $(\%)$ & 0.089 & 0.082 \\
\hline $\begin{array}{l}\text { Cation exchange capacity } \\
\left(\mathrm{cmol}(+) \mathrm{kg}^{-1}\right)\end{array}$ & 13.97 & 11.40 \\
\hline Bulk density $\left(\mathrm{g} \mathrm{cm}^{-3}\right)$ & 1.234 & 1.298 \\
\hline \multicolumn{3}{|l|}{ Particle size distribution } \\
\hline Clay $(\%)$ & 22.46 & 8.46 \\
\hline Silt $(\%)$ & 12.00 & 10.00 \\
\hline Sand $(\%)$ & 65.54 & 81.54 \\
\hline
\end{tabular}

(1994). Table 1 presents the physico-chemical properties of the soil at both sites. The field was flooded, ploughed, puddled thoroughly to $15 \mathrm{~cm}$ depth and levelled. Rice plants (25-day old seedlings of cv. 'Gayatri') were transplanted in early July, 1996 at a spacing of $20 \mathrm{~cm} \times 10 \mathrm{~cm}$ in field plots $(8 \mathrm{~m} \times 6 \mathrm{~m})$, well separated by levees. Incessant rains from the second week of June to the last week of August are typical of the monsoon season at Cuttack. Rainfall during June-November was $685 \mathrm{~mm}$ and the temperature varied between $34.2^{\circ} \mathrm{C}$ and $25.3^{\circ} \mathrm{C}$. In the rainfed lowland field plots, there was no provision for natural surface drainage. Water percolation rate was also negligible because of a high water table especially in the wet season and except during April-May the soil at this site continued to be moist.

In the first experiment under rainfed lowland conditions, the depth of floodwater remained at $30 \pm 10 \mathrm{~cm}$ during June-October, 1996. Prilled urea, urea supergranule and a mixture of prilled urea and a nitrification inhibitor, Nimin [Neem triterpenes, Godrej Agrovet Limited, Bombay, 1:100 ratio (nitrification inhibitor: urea, w/w)] were applied at an uniform rate of $60 \mathrm{~kg} \mathrm{Nha}^{-1}$. The plots without $\mathrm{N}$ application served as a control. The prilled urea or the mixture of prilled urea and Nimin was broadcast to the pre-flooded field plots, just before transplanting as practised by most of the local farmers in rainfed lowland rice. Urea granules (about $1 \mathrm{~g}$ granule ${ }^{-1}$ ) were placed manually between the rows of rice plants in the reduced zone of soil $(<5 \mathrm{~cm}$ depth) just before transplanting. 
In the second experiment under irrigated shallow rice field conditions, the floodwater depth was maintained at 4-6 cm by irrigation throughout the growing season. Prilled urea, green manure (Sesbania rostrata) and prilled urea in combination with green manure were applied to provide $60 \mathrm{~kg} \mathrm{Nha}^{-1}$. Prilled urea was broadcast just before transplanting as done in the earlier experiment. Green manure, Sesbania rostrata plants were grown in the field plots during the second week of May to the first week of July, 1996. A week before transplanting rice, Sesbania plants were uprooted and cut into $5-10 \mathrm{~cm}$ pieces and incorporated into the soil. In the treatment receiving green manure alone, manure was applied to provide $60 \mathrm{~kg} \mathrm{Nha}^{-1}$ (dry weight basis). In treatments receiving prilled urea + green manure, the required quantity of green manure to provide $30 \mathrm{~kg} \mathrm{~N}^{-1}$ was first incorporated in the soil seven days before transplanting and prilled urea at $30 \mathrm{~kg} \mathrm{Nha}^{-1}$ was then applied on the day of transplanting to provide a total of $60 \mathrm{~kg} \mathrm{Nha}^{-1}$. In both experiments, all fertilizers were applied as basal. Both the experiments were conducted in a randomized block design with five replicates for each treatment in plots of $8 \mathrm{~m} \times 6 \mathrm{~m}$.

\subsection{Methane flux measurements}

Methane emission from flooded rice fields was monitored using the static chamber technique as described by Adhya et al. (1994) and Parashar et al. (1996). The assembly consisted of permanently installed aluminium bases $(30 \mathrm{~cm} \times 50 \mathrm{~cm})$ with a U-shaped channels to hold perspex boxes $(30 \mathrm{~cm} \times 50 \mathrm{~cm} \times 76 \mathrm{~cm})$ and water to provide air-tight conditions. At each sampling, perspex boxes were placed in the channel over the rice canopy and sealed air-tight to determine the linear rate of methane increase. A battery-operated air circulation pump (AeroVironment, Monrovia, CA, USA) with a flow rate of $1.51 \mathrm{~min}^{-1}$, connected with polyethylene tubes via a three-way stopcock, mixed the air inside the chamber. The headspace gas of the chamber was collected in gas sampling bags (Tedlar ${ }^{\circledR}$ DuPont, AeroVironment) at intervals of 0,15 , and $30 \mathrm{~min}$ for each treatment. Immediately after sampling, the concentration of methane was analysed in a Varian 3600 gas chromatograph as described earlier (Ramakrishnan et al., 1995). The minimum detectable limit was approximately $0.5 \mu \mathrm{g}$ in a $1 \mathrm{ml}$ gas sample. Gas chromatograph was calibrated periodically using $1 \mu \mathrm{CH}_{4} 1^{-1}$ in $\mathrm{N}_{2}$, obtained from M/s Mathesons, USA as primary standard and 1.94, 2.60, 4.40 and $10.9 \mu \mathrm{C} \mathrm{CH}_{4} \mathrm{l}^{-1}$ in $\mathrm{N}_{2}$ as secondary standards, prepared from $0.05 \%$ methane in argon by static dilution technique. Samplings were done twice a day (9.00-9.30 a.m. and 3.00-3.30 p.m.) at specific plant growth stages. Floodwater depth, soil and water temperature, plant height and volume, chamber temperature and headspace height were recorded at each gas collection time. Methane flux was calculated from the temporal increase of the methane concentration inside the box using the equation of Parashar et al. (1996) and the average of morning and evening fluxes was considered as the flux value for the day. Cumulative methane emission for the entire growth period was computed by plotting the methane efflux values against the days of sampling and the area covered under the plot of such relationship was expressed as $\mathrm{g} \mathrm{m}^{-2}$.

\subsection{Methane production measurements}

In another experiment, air-dried soil samples ( $5 \mathrm{~g})$ from the irrigated shallow rice experimental field plots were placed in $18 \mathrm{ml}$ glass tubes which were closed with a rubber septum to allow gas sampling from the head space. Flooding of the soil samples was done with different amounts of sterile water to provide varying water levels (i.e. 5, 8, 10.5, 14, 17 and $20 \mathrm{~mm}$ above the soil surface). The tubes were incubated at $37^{\circ} \mathrm{C}$ and periodic gas sampling was done from the head space after releasing the trapped methane from soils by shaking the contents of tubes thoroughly for $1 \mathrm{~min}$. Replicate soil tubes (5) of each treatment were sacrificed at each sampling. Methane determinations were made by flame ionization detection gas chromatography (Ramakrishnan et al., 1995) and the concentrations were represented as $n g \mathrm{CH}_{4} \mathrm{~g}^{-1}$ of dry soil.

\subsection{Chemical analyses}

On each methane flux measurement day, soil samples were collected between the rows of rice plants using polyvinylchloride soil-core $(8.5 \mathrm{~cm}$ inner diameter). Root fragments and stones were removed manually from the composite soil samples. Moisture 
Table 2

Methane efflux from rainfed lowland rice fields plots planted to cv. Gayatri, as influenced by fertilizer management

\begin{tabular}{|c|c|c|c|c|c|c|c|c|c|}
\hline \multirow[t]{3}{*}{ Treatment } & \multicolumn{9}{|c|}{ Methane efflux* $\left(\mathrm{mg} \mathrm{m}^{-2} \mathrm{~h}^{-1}\right)$} \\
\hline & \multicolumn{9}{|c|}{ Days after transplanting (DAT) } \\
\hline & 30 & 50 & 70 & 85 & 100 & 110 & 125 & 130 & 140 \\
\hline Control & $8.3^{\mathrm{a}}$ & $21.0^{\mathrm{a}}$ & $39.9^{\mathrm{a}}$ & $90.7^{\mathrm{a}}$ & $62.8^{\mathrm{a}}$ & $75.1^{\mathrm{a}}$ & $102.9^{\mathrm{a}}$ & $58.7^{\mathrm{a}}$ & $8.2^{\mathrm{a}}$ \\
\hline Prilled urea & $5.7^{\mathrm{a}}$ & $13.1^{\mathrm{a}}$ & $26.8^{\mathrm{a}}$ & $67.2^{\mathrm{ab}}$ & $71.6^{\mathrm{a}}$ & $85.2^{\mathrm{a}}$ & $94.3^{\mathrm{a}}$ & $28.5^{\mathrm{b}}$ & $7.8^{\mathrm{a}}$ \\
\hline Prilled urea + Nimin & $5.2^{\mathrm{a}}$ & $17.7^{\mathrm{a}}$ & $27.1^{\mathrm{a}}$ & $48.0^{\mathrm{c}}$ & $51.0^{\mathrm{b}}$ & $64.8^{\mathrm{b}}$ & $77.2^{\mathrm{b}}$ & $21.7^{\mathrm{b}}$ & $7.4^{\mathrm{a}}$ \\
\hline Urea supergranule & $6.1^{\mathrm{a}}$ & $13.2^{\mathrm{a}}$ & $30.7^{\mathrm{a}}$ & $58.4^{\mathrm{c}}$ & $57.6^{\mathrm{b}}$ & $74.3^{\mathrm{a}}$ & $90.2^{\mathrm{a}}$ & $56.2^{\mathrm{a}}$ & $12.3^{\mathrm{a}}$ \\
\hline
\end{tabular}

* Mean of four replicate observations. In a column, means followed by a common letter are not significantly different at the $5 \%$ level by DMRT.

Table 3

Effect of fertilizer management practices on methane efflux from irrigated shallow rice field plots planted to cv. Gayatri

\begin{tabular}{|c|c|c|c|c|c|c|c|}
\hline \multirow[t]{3}{*}{ Treatment } & \multicolumn{7}{|c|}{ Methane efflux* $\left(\mathrm{mg} \mathrm{m}^{-2} \mathrm{~h}^{-1}\right)$} \\
\hline & \multicolumn{7}{|c|}{ Days after transplanting (DAT) } \\
\hline & 25 & 40 & 60 & 75 & 90 & 105 & 120 \\
\hline Control & $2.9^{\mathrm{c}}$ & $9.5^{\mathrm{c}}$ & $9.8^{\mathrm{d}}$ & $8.9^{\mathrm{b}}$ & $6.7^{\mathrm{c}}$ & $0.9^{\mathrm{b}}$ & $0.4^{\mathrm{b}}$ \\
\hline Prilled urea & $16.7^{\mathrm{a}}$ & $16.5^{\mathrm{b}}$ & $18.7^{\mathrm{b}}$ & $14.7^{\mathrm{a}}$ & $9.7^{\mathrm{b}}$ & $3.2^{\mathrm{a}}$ & $0.4^{\mathrm{b}}$ \\
\hline Green manure & $19.8^{\mathrm{a}}$ & $9.6^{\mathrm{c}}$ & $13.7^{\mathrm{c}}$ & $14.5^{\mathrm{a}}$ & $11.7^{\mathrm{ab}}$ & $2.2^{\mathrm{ab}}$ & $2.2^{\mathrm{a}}$ \\
\hline Prilled urea + Green manure & $7.6^{\mathrm{b}}$ & $36.8^{\mathrm{a}}$ & $32.7^{\mathrm{a}}$ & $15.3^{\mathrm{a}}$ & $14.1^{\mathrm{a}}$ & $2.3^{\mathrm{ab}}$ & $3.3^{\mathrm{a}}$ \\
\hline
\end{tabular}

* Mean of four replicate observations. In a column, means followed by a common letter are not significantly different at the $5 \%$ level by DMRT.

content was determined in $10 \mathrm{~g}$ portions by gravimetric analysis.

Ninhydrin reactive nitrogen (NRN) and readily mineralizable carbon (RMC) content in further $10 \mathrm{~g}$ subsamples were extracted with $0.5 \mathrm{M} \mathrm{K}_{2} \mathrm{SO}_{4}$. NRN content in soil samples was estimated colorimetrically after mixing the soil extract $(1 \mathrm{ml})$ with ninhydrin solution $(5 \mathrm{ml})$ and incubating the mixture in a hot water bath for $7.5 \mathrm{~min}$ (Budalucco et al., 1992). The RMC content in soil samples was estimated by digesting the soil extracts with dichromate and then, titrating against $0.25 \mathrm{~N} \mathrm{FeSO}_{4}$ using diphenylamine indicator (Vance et al., 1987). The soil redox potentials in the experimental sites were monitored at $5 \mathrm{~cm}$ depth with a portable oxidation-reduction potential meter (Barnant Company, IL, USA) periodically. Using wet soil samples, the soil $\mathrm{pH}$ was determined in a digital $\mathrm{pH}$ meter.

\subsection{Measurement of plant biomass}

Aerial biomass (fresh and dry weight) of plants was measured by harvesting the above ground portions on each day of sampling for methane efflux. Grains and straw from the individual plots were harvested separately and dried to determine the biomass.

\subsection{Statistical analysis}

Data were analysed by the standard statistical methods using IRRISTAT (version 3/93, International Rice Research Institute, Los Banos, 1993). The significance of the differences between treatments was assessed by ANOVA and subsequently by Duncan's multiple range test (DMRT).

\section{Results and discussion}

\subsection{Methane emission from rainfed lowland rice}

In the first experiment during the wet season of 1996, methane emission peaked during 100-125 days after transplanting followed by a decline. Methane emission from lowland rice field was little affected by the broadcast application of prilled urea (Table 
Table 4

Plant biomass production and the cumulative methane efflux from shallow irrigated and rainfed lowland rice fields planted to cv. Gayatri

\begin{tabular}{|c|c|c|c|}
\hline \multirow[t]{2}{*}{ Treatment } & \multicolumn{2}{|c|}{ Plant biomass production $\left(\mathrm{tha}^{-1}\right)$} & \multirow[t]{2}{*}{ Cumulative methane emission $\left(\mathrm{g} \mathrm{m}^{-2}\right)$} \\
\hline & Straw yield & Grain yield & \\
\hline \multicolumn{4}{|l|}{ Rainfed lowland field plots } \\
\hline Control & 8.38 & 5.04 & 347.5 \\
\hline Prilled urea & 8.48 & 5.52 & 307.5 \\
\hline Prilled urea + Nimin & 10.07 & 5.48 & 255.0 \\
\hline Urea supergranule & 10.97 & 6.22 & 295.0 \\
\hline \multicolumn{4}{|l|}{ Irrigated shallow field plots } \\
\hline Control & 5.87 & 4.10 & 38.8 \\
\hline Prilled urea & 7.37 & 4.90 & 73.8 \\
\hline Green manure & 8.51 & 5.60 & 70.0 \\
\hline Prilled urea + Green manure & 8.19 & 5.80 & 116.3 \\
\hline
\end{tabular}

2). The subsurface application of urea supergranules was marginally effective in reducing the methane flux over that in control, especially during 85-100 days after transplanting. Interestingly, emission of methane was the lowest in plots treated with the mixture of prilled urea and Nimin, a nitrification inhibitor which inhibits the autotrophic oxidation of $\mathrm{NH}_{4}{ }^{+}$to $\mathrm{NO}_{2}{ }^{-}$ (Sahrawat and Parmar, 1975). Nitrification inhibitors are also known to inhibit methane oxidation (Bronson and Mosier, 1994). Lindau et al. (1993) reported that some nitrification inhibitors can mitigate methane emissions from rice fields. In a microplot study with dry-seeded flooded rice, application of nitrification inhibitors, nitrapyrin and wax-coated calcium carbide in particular, retarded methane emission significantly (Keerthisinghe et al., 1993). The decrease in methane emission in plots treated with wax-coated calcium carbide was attributed to a direct result of the slow release of acetylene, a known inhibitor of methanogenesis (Bronson and Mosier, 1991). The mechanism of inhibitory action of Nimin on methane emission as seen in the present study is not known. These results suggest that the influence of urea on methane emission is dependent on the form and more importantly on its application, with or without nitrification inhibitors. A number of studies have demonstrated the strong effects of nitrogenous fertilizers on methane efflux from rice paddies (Wang et al., 1992; Lindau et al., 1993; Minami, 1995) although the interrelationship between the fertilizer nitrogen and methane emission from rice fields needs further research.

\subsection{Methane emission from irrigated shallow rice}

The experiment under irrigated shallow conditions showed that the application of prilled urea and green manure significantly enhanced methane emission (Table 3). Prilled urea or green manure at $60 \mathrm{~kg} \mathrm{Nha}^{-1}$ effected a 1.5-2-fold increase in methane emission over that in control. Application of green manure in combination with prilled urea further enhanced methane emission significantly over that in treatments with prilled urea and green manure alone. Interestingly, the stimulatory effect of green manure, alone or in combination with prilled urea was evident even after 120 days from transplanting (127 days after application of green manure). Application of organic sources is known to enhance methane emission from flooded rice fields (Yagi and Minami, 1990). Denier van der Gon and Neue (1995) reported higher methane emission from green manure-amended field plots than in urea-treated plots. In the present experiments, methane emission was the highest in plots treated with the combination of green manure and prilled urea, possibly as a result of more favourable soil $\mathrm{C}: \mathrm{N}$ ratio and resultant promotion of microbial activities. Soil C: $\mathrm{N}$ ratio is an important parameter affecting methane production in flooded soils (Wang et al., 1992). The higher methane emission arising from fertilizer application is often attributed to enhanced plant biomass. The methane emission from rice fields is positively correlated generally, but with some exceptions, with plant biomass (Sass et al., 1990; Neue and Roger, 1993; Sinha, 1995). 

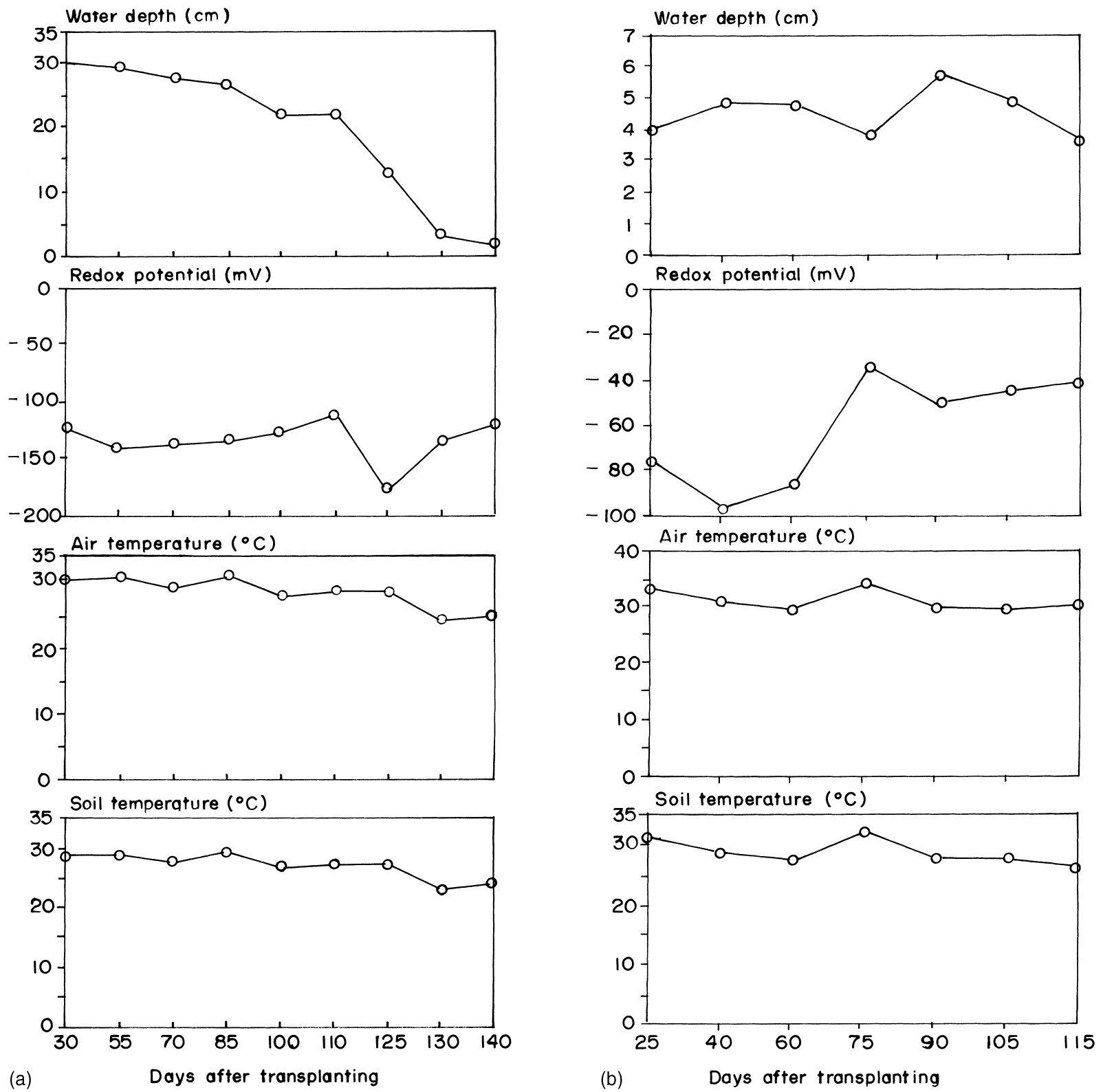

Fig. 1. Variation in floodwater depth $(\mathrm{cm})$, redox potential $(\mathrm{mV})$ of flooded soil, ambient temperature and soil surface temperature of (a) rainfed lowland and (b) irrigated shallow rice experimental sites.

The experiments here were planted to the same cultivar. Among the physico-chemical properties of the soil samples from both sites, appreciable differences existed with regard to $\mathrm{pH}$ and electrical conductivity, and the contents of clay, sand and silt (Table 1).
The levels of total carbon and nitrogen were, however, similar at both sites. Interestingly, in control and prilled urea-treated plots, methane emission under rainfed lowland conditions was 4-10 times higher than that under irrigated shallow conditions (Table 4). 
Increased methane emission from rainfed lowland rice fields could be attributed to continuous deep submergence for a prolonged period (70 days) in comparison with shallow irrigation (Fig. 1a, b). However, methane efflux in rainfed lowland rice fields, from 130 to 140 days after transplanting, decreased with decreasing water depth (Table 2). The data presented in Fig. 1(a, b) also show a more rapid drop in redox potential under rainfed lowland conditions than in irrigated shallow rice fields. Rapid drop in soil redox potential would be congenial for methanogenic activities (Wang et al., 1993). Moreover, rainfed lowland field plots produced more plant biomass than that in irrigated shallow fields (Table 4). The growth and biomass productivity of rice cultivars are known to differ in ecosystems with varying water regimes (Muralidharan et al., 1996). In the present study, methane emission from the two sites appeared to be positively related to the plant biomass of the cultivar. A positive relationship between plant biomass and methane emission appears logical because about $80-90 \%$ of methane emitted to the atmosphere from flooded rice fields is transported through rice plants (Cicerone and Shetter, 1981). In rainfed lowland plots, maturity duration of cv. Gayatri was about 20 days more than with shallow irrigation and the prolonged vegetative period could lead to a significant increase in cumulative methane emission.

\subsection{Methane production in alluvial soil as influenced by water levels}

In order to understand the influence of floodwater level on methanogenesis, methane production was measured in terms of the increase in the concentration of methane in the head space of the tubes containing soil samples, experimentally flooded with sterile water to provide different water levels above the soil surface (Table 5). During the initial 20 days of incubation, there was no appreciable increase in the concentrations of methane among treatments. However, after 20 days, methane production from soil samples was distinctly enhanced with the increase in water level. Flooding of soil results in a low rate of oxygen diffusion and anaerobiosis occurs, in a thermodynamic sequence (Ponnamperuma, 1972). Soil samples in tubes with a head space that contained oxygen and flooded with water, as in the present experiment, established anaerobiosis depending on the diffusion and consump- tion of oxygen. Distinct stimulation of methane production in soil samples with increased water level suggests that the development of anaerobic conditions was rapid and favourable to methanogenesis.

\subsection{Availability of $C$ and $N$ substrates}

Under rainfed lowland conditions, the ninhydrin reactive nitrogen (NRN) content was the lowest in plots treated with the mixture of prilled urea and Nimin (Table 6). Subsurface application of urea supergranules also reduced the level of NRN. These changes of NRN content in field plots could be related to the rates of methane emission. The higher the content of NRN in soil, the higher was the methane emission rate.

Similarly, a positive relationship between the NRN content and the rate of methane emission from the shallow irrigated field plots was observed. The contents of NRN were more in organic and inorganic $\mathrm{N}$ fertilizer treated plots (Table 7 ). Likewise, the carbon content of soil samples, measured as readily mineralizable carbon, also showed a variable trend. In the rainfed lowland rice field plots, the readily mineralizable carbon (RMC) content peaked during 110 days after transplanting (Table 6); the amount of methane emitted could be related to the RMC content of soil samples. In irrigated shallow rice fields, RMC content was highest in plots treated with prilled urea in combination with green manure and lowest in untreated control the (Table 7). Yagi and Minami (1990) also reported that the available carbon content, measured in terms of RMC, influences methane efflux from flooded soils.

\section{Conclusions}

According to the data presented in this study, the use of the nitrification inhibitors such as Nimin or placement of urea supergranule in flooded rice fields can be considered as suitable options for mitigating methane emission from rice fields without affecting grain yield. These measures can serve the dual purpose of not only improving $\mathrm{N}$-use efficiency in lowland rice but also regulating methane emission from the rice fields. The study further reveals that when the same rice cultivar is grown under two different hydrological situations the methane emission potential greatly differed. This 
Table 5

Methane production in soil samples, experimentally flooded to provide different water levels

\begin{tabular}{|c|c|c|c|c|c|c|c|c|}
\hline \multirow[t]{3}{*}{ Water level (mm) } & \multicolumn{8}{|c|}{ ng of methane produced $\mathrm{g}^{-1}$ soil $^{*}$} \\
\hline & \multicolumn{8}{|c|}{ Days of incubation } \\
\hline & 5 & 10 & 15 & 20 & 25 & 30 & 35 & 40 \\
\hline 5.0 & $4.5^{\mathrm{a}}$ & $31.7^{\mathrm{a}}$ & $77.3^{\mathrm{a}}$ & $235.1^{\mathrm{a}}$ & $2381.3^{\mathrm{e}}$ & $11076.7^{\mathrm{f}}$ & $15033.7^{\mathrm{f}}$ & $21345.2^{\mathrm{f}}$ \\
\hline 8.0 & $4.9^{\mathrm{a}}$ & $40.7^{\mathrm{a}}$ & $113.0^{\mathrm{a}}$ & $365.4^{\mathrm{a}}$ & $4110.5^{\mathrm{d}}$ & $19809.1^{\mathrm{e}}$ & $21973.4^{e}$ & $25179.7^{\mathrm{e}}$ \\
\hline 10.5 & $5.8^{\mathrm{a}}$ & $32.9^{\mathrm{a}}$ & $170.4^{\mathrm{a}}$ & $496.2^{\mathrm{a}}$ & $5849.3^{c}$ & $23978.5^{\mathrm{d}}$ & $26464.6^{\mathrm{d}}$ & $29488.1^{\mathrm{d}}$ \\
\hline 14.0 & $10.8^{\mathrm{a}}$ & $23.8^{\mathrm{a}}$ & $221.3^{\mathrm{a}}$ & $546.7^{\mathrm{a}}$ & $6544.5^{\mathrm{bc}}$ & $26517.6^{\mathrm{c}}$ & $29681.1^{\mathrm{c}}$ & $36814.2^{\mathrm{c}}$ \\
\hline 17.0 & $4.0^{\mathrm{a}}$ & $46.0^{\mathrm{a}}$ & $283.9^{\mathrm{a}}$ & $611.1^{\mathrm{a}}$ & $7277.1^{\mathrm{ab}}$ & $30733.2^{\mathrm{b}}$ & $33708.7^{b}$ & $40242.3^{\mathrm{b}}$ \\
\hline 20.0 & $4.0^{\mathrm{a}}$ & $44.1^{\mathrm{a}}$ & $311.0^{\mathrm{a}}$ & $1108.3^{\mathrm{a}}$ & $8034.2^{\mathrm{a}}$ & $32352.4^{\mathrm{a}}$ & $37489.3^{\mathrm{a}}$ & $43537.5^{\mathrm{a}}$ \\
\hline
\end{tabular}

* Mean of five replicate observations. In a column, means followed by a common letter are not significantly different at the 5\% level by DMRT.

Table 6

Changes in ninhydrin reactive nitrogen (NRN) $\left(\mu \mathrm{gg}^{-1}\right.$ soil) and readily mineralizable carbon $(\mathrm{RMC})\left(\mu \mathrm{gg} \mathrm{g}^{-1}\right.$ soil) content of rainfed lowland rice field plots planted to cv. Gayatri*

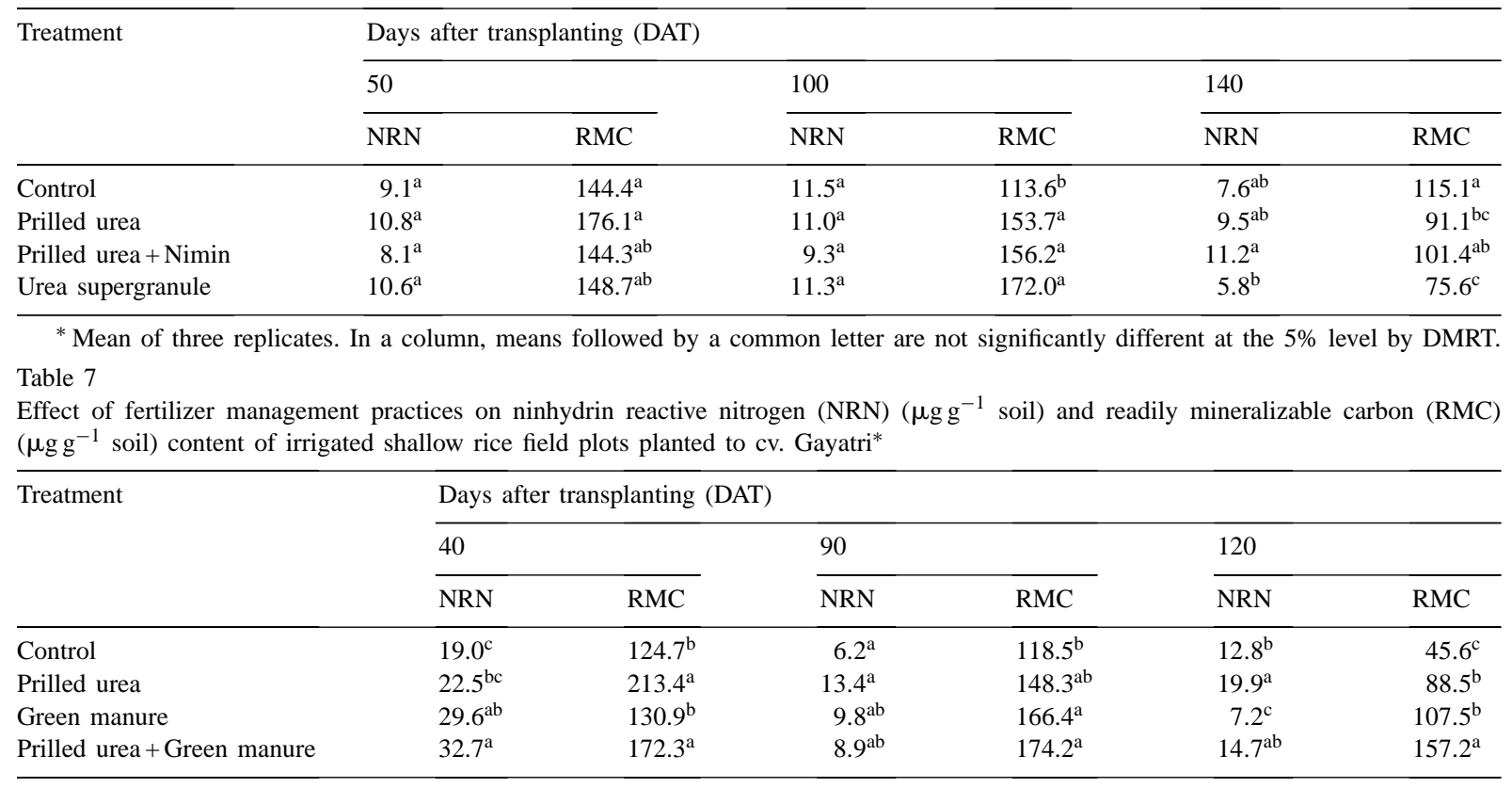

* Mean of three replicates. In a column, means followed by a common letter are not significantly different at the 5\% level by DMRT.

opens up the possibilities of developing suitable management schedules for regulating methane emission from flooded rice paddies.

\section{Acknowledgements}

The authors thank Dr. K.C. Mathur (Director) for permission to publish this work, the Indian Council of Agricultural Research, New Delhi for funding this project and the Council of Scientific and Industrial Research, New Delhi for a research fellowship grant to Mr. Arun Kumar Rath.

\section{References}

Adhya, T.K., Rath, A.K., Gupta, P.K., Rao, V.R., Das, S.N., Parida, K.M., Parashar, D.C., Sethunathan, N., 1994. Methane emission from flooded rice fields under irrigated conditions. Biol. Fertil. Soils 18, 245-248. 
Adhya, T.K., Patnaik, P., Satpathy, S.N., Kumaraswamy, S., Sethunathan, N., 1998. Influence of phosphorus application on methane emission and production in flooded paddy soils. Soil Biol. Biochem. 30, 177-181.

Bhadrachalam, A., Chakravorti, S.P., Banerjee, N.K., Mohanty, S.K., Mosier, A.R., 1992. Denitrification in intermittently flooded rice fields and $\mathrm{N}$-gas transport through rice plants. Ecol. Bull. 42, 183-187.

Bronson, K.F., Mosier, A.R., 1991. Effect of encapsulated calcium carbide on dinitrogen, nitrous oxide, methane and carbon dioxide emissions from flooded rice. Biol. Fertil. Soils 11, 116120.

Bronson, K.F., Mosier, A.R., 1994. Suppression of methane oxidation in aerobic soil by nitrogen fertilizers, nitrification inhibitors and urease inhibitors. Biol. Fertil. Soils 17, 263-268.

Budalucco, L., Gelsomino, A., Orco, S.D., Grego, S., Nannipieri, P., 1992. Biochemical characterization of soil organic compounds extracted by $0.5 \mathrm{M} \mathrm{K} \mathrm{K}_{2} \mathrm{SO}_{4}$ before and after chloroform fumigation. Soil Biol. Biochem. 24, 569-578.

Cicerone, R.J., Shetter, J.D., 1981. Sources of atmospheric methane : Measurements in rice paddies and a discussion. J. Geophys. Res. 86, 7203-7209.

Cribbs, W.H., Mills, H.A., 1979. Influence of nitrapyrin on the evolution of $\mathrm{N}_{2} \mathrm{O}$ from organic medium with and without plants. Commun. Soil Sci. Plant Anal. 10, 785-794.

Denier van der Gon, H.A.C., Neue, H.U., 1995. Influence of organic matter incorporation on the methane emission from a wetland rice field. Global Biogeochem. Cycles 9, 11-22.

Keerthisinghe, D.G., Freney, J.R., Mosier, A.R., 1993. Effect of wax-coated calcium carbide and nitrapyrin on nitrogen loss and methane emission from dry-seeded flooded rice. Biol. Fertil. Soils 16, 71-75.

Kimura, M., 1992. Methane emission from paddy soils in Japan and Thailand. In: Batjes, N.H., Bridges, E.M. (Eds.), World inventory of soil emission potentials. WISE report 2, International Soil Reference and Information Centre, Wageningen, pp. 43-79.

Lindau, C.W., Bollich, P.K., DeLaune, R.D., 1995. Effect of rice variety on methane emission from Louisiana rice. Agric. Ecosyst. Environ. 54, 109-114.

Lindau, C.W., Bollich, P.K., DeLaune, R.D., Mosier, A.R., Bronson, K.F., 1993. Methane mitigation in flooded Louisiana rice fields. Biol. Fertil. Soils 15, 174-178.

Mikkelsen, D.S., De Datta, S.K., Obamea, W.N., 1978. Ammonia volatilization losses from flooded rice soils. Soil Sci. Soc. Am. J. $42,725-730$.

Minami, K., 1995. The effect of nitrogen fertilizer use and other practices on methane emission from flooded rice. Fert. Res. 40, 71-84.

Mishra, S., Rath, A.K., Adhya, T.K., Rao, V.R., Sethunathan, N., 1997. Effect of continuous and alternate water regimes on methane efflux from rice under greenhouse conditions. Biol. Fertil. Soils 24, 399-405.

Muralidharan, K., Prasad, G.S.V., Rao, C.S., 1996. Breeding for rice improvement: Where do we stand. Curr. Sci. 71, 438-448.

Neue, H.U., Roger, P.A., 1993. Rice agriculture: Factors controlling emissions. In: Khalil, M.A.K. (Ed.), The Global Cycle of Methane: Source, Sinks, Distribution and Role In Global Change. NATO Advanced Science Series, Springer, Berlin, pp. 254-298.

Parashar, D.C., Mitra, A.P., Gupta, P.K., Rai, J., Sharma, R.C., Singh, N., Koul, S., Ray, H.S., Das, S.N., Parida, K.M., Rao, S.B., Kanungo, S.P., Ramasami, T., Nair, B.U., Swamy, M., Singh, G., Gupta, S.K., Singh, A.R., Saikia, B.K., Barua, A.K.S., Pathak, M.G., Iyer, C.S.P., Gopalakrishnan, M., Sane, P.V., Singh, S.N., Banerjee, R., Sethunathan, N., Adhya, T.K., Rao, V.R., Palit, P., Saha, A.K., Purkait, N.N., Chaturvedi, G.S., Sen, S.P., Sen, M., Sarkar, B., Banik, A., Subbaraya, B.H., Lal, S., Venkatramani, S., Lal, G., Chaudhary, A., Sinha, S.K., 1996. Methane budget from paddy fields in India. Chemosphere 33, 737-757.

Ponnamperuma, F.N., 1972. The chemistry of submerged soils. Adv. Agron. 24, 29-96.

Prasad, R., Power, J.F., 1995. Nitrification inhibitors for agriculture, health and environment. Adv. Agron. 54, 233-281.

Ramakrishnan, B., Satpathy, S.N., Patnaik, P., Adhya, T.K., Rao, V.R., Sethunathan, N., 1995. Methane production in two Indian rice soils. Geomicrobiol. J. 13, 193-199.

Sahrawat, K.L., Parmar, B.S., 1975. Alcohol extract of neem (Azadirachta indica L.) seed as nitrification inhibitor. J. Indian Soc. Soil Sci. 23, 131-134.

Sass, R.L., Fisher, F.M., Harcombe, P.A., Turner, F.T., 1990. Methane production and emission in a Texas rice field. Global Biogeochem. Cycles 4, 47-68.

Satpathy, S.N., Mishra, S., Adhya, T.K., Ramakrishnan, B., Rao, V.R., Sethunathan, N., 1998. Cultivar variation in methane efflux from tropical rice. Plant Soil 202, 223-229.

Sinha, S.K., 1995. Global methane emission from rice paddies: Excellent methodology but poor extrapolation. Curr. Sci. 68, 643-646.

Vance, E.D., Brookes, P.C., Jenkinson, D.S., 1987. An extraction method for measuring microbial biomass C. Soil Biol. Biochem. 19, 703-707.

Wang, Z.P., DeLaune, R.D., Lindau, C.W., Patrick Jr., W.H., 1992 Methane production from anaerobic soil amended with rice straw and nitrogen fertilizers. Fert. Res. 33, 115-121.

Wang, Z.P., DeLaune, R.D., Masscheleyn, P.H., Patrick Jr., W.H., 1993. Soil redox and $\mathrm{pH}$ effects on methane production in a flooded rice soil. Soil Sci. Soc. Am. J. 57, 382-385.

Yagi, K., Minami, K., 1990. Effect of organic matter application on methane emission from some Japanese paddy fields. Soil Sci. Plant Nutr. 36, 599-610. 